\title{
The Toxicity of Srikaya Seed Granules (Annona squamosa L.) with Different Heating Temperatures Against the Larva of Aedes aegypti L.
}

\author{
Dwi Wahyuni $^{1}$, Joko Waluyo ${ }^{2}$, Rima Gloria Purwanto ${ }^{3}$ \\ Biology Education, Faculty of Teacher Training and Education, University of Jember \\ Kalimantan Street, Tegal Boto, Jember 68121 \\ E-mail: dwiwahyuni_fkip@unej.ac.id
}

\begin{abstract}
Aedes aegypti L. contains the virus that causes dengue fever, especially in Southeast Asia. Fogging and using chemicals such as Abate control the mosquito, but on the other hand, it causes Aedes aegypti L. to become resistant. A breakthrough is needed to eradicate the mosquito, which is environmentally friendly, less harmful to non-target animals, and avoid Aedes aegypti L. resistance. The seed of Annona squamosa L. contains annonain and squamosin known to have a toxic effect on the larvae of Aedes aegypti $\mathrm{L}$. Further research is needed to test the heating level of the seed extract granules to find out the more effective treatment to the larvae. This research method uses a completely randomized design with two treatments, six sub treatments, and four repetitions. The temperature of $60^{\circ} \mathrm{C}$ uses concentrations of $1 \mathrm{ppm}, 6 \mathrm{ppm}, 12 \mathrm{ppm}, 18 \mathrm{ppm}, 24 \mathrm{ppm}$, and $30 \mathrm{ppm}$. As for the temperature of 40 ${ }^{\circ} \mathrm{C}$ using concentrations of $1 \mathrm{ppm}, 7 \mathrm{ppm}, 14 \mathrm{ppm}, 21 \mathrm{ppm}, 28 \mathrm{ppm}$, and $35 \mathrm{ppm}$. Each temperature is compared with aquadest and Abate. Data is analyzed using probit analysis to determine the LC50, followed by a paired sample T-test to find out the significant difference. The result showed a higher temperature $\left(60^{\circ} \mathrm{C}\right)$ has a higher level of toxicity compared to $40^{\circ} \mathrm{C}$.
\end{abstract}

Keywords: Annona squamosa seed extract granules, Aedes aegypti larvae, temperature.

\section{PRELIMINARY}

Aedes aegypti $\mathrm{L}$ is a vector of dengue virus that causes a DHF disease (Sembel, 2009). According to data from the WHO organization from 1968 to 2009, Indonesia was the country with the highest DHF cases in Southeast Asia. It was ranked the highest in the world with the second dengue case after Thailand (Martini et al., 2014).

The effort carried out by the government is using simple methods such as fogging to suppress the DHF disease. The active organophosphate and pyrethroid are used in fogging. Unfortunately, organophosphate, pyrethroid, and abate are no longer work for the Aedes aegypti $\mathrm{L}$.

One natural source that has the potential as larvacide is the Annona squamosa L. This fruit is commonly known as srikaya in Indonesia. The seed of srikaya fruit known to have insecticidal ingredients. Unripe fruit contains acetogenin, glycosides, alkaloids, flavonoids, phytosterols, steroids, saponins, volatile compounds, cyclic ketones, long-chain fatty acids, terpenoids, tannin, phenol, verbenone, and borneol (Kowsalya, 2014).
The active insecticidal ingredients are mostly obtained from the srikaya flesh. Acetogenin and other phenolic compounds are potent to kill insects and herbivorous animals, while verbenone and borneol can repel insects. Verbenone and borneol also found in the fruit skin (Kumar, 2009).

Srikaya seeds contain chemicals consisting of squamosin and asimicin (Hermianto et al., 2004). The composition of fatty acids in srikaya seed oil consists of metal palmitate, metal stearic, methyl linoleic, which are larvicidal (Taslimah, 2014).

This study aims to determine the differences in the toxicity (LC50) of srikaya (Annona squamosa L.) seed extract granules based on different heating treatments $\left(40^{\circ} \mathrm{C}\right.$ and $60^{\circ} \mathrm{C}$ ) using 24-hour deduction time against the larvae Aedes aegypti L.

\section{RESEARCH METHODS}

\section{Maintenance Phase}

The larvae are fed with Takari fish every day by crushing fish feed using mortar and pistil. Feeding is given once a day, then observed the process of changing the skin so the stage of the larvae can be determined. The feeding continues 
until the larvae reach the age of late $3^{\text {rd }}$ instar until the initial of $4^{\text {th }}$ instar. The test larvae are homogeneous and healthy, seen from the agile movement of larvae.

\section{Identification Phase}

The identification of test larvae is carried out microscopically and macroscopically. The parameters include the size, color, siphon, shape, lateral spines, and the resting phase of larvae.

\section{Preliminary Test of The Granules}

Preliminary tests were carried out to determine the concentrations suitable for killing at least 20 larvae. The levels or concentrations used for $40^{\circ} \mathrm{C}$ are $1 \mathrm{ppm}, 2 \mathrm{ppm}, 3 \mathrm{ppm}, 5 \mathrm{ppm}$, $25 \mathrm{ppm}, 30 \mathrm{ppm}$, and $35 \mathrm{ppm}$, whereas the temperature for $60^{\circ} \mathrm{C}$ is $1 \mathrm{ppm}, 2 \mathrm{ppm}, 3 \mathrm{ppm}$, $25 \mathrm{ppm}, 27 \mathrm{ppm}$, and $30 \mathrm{ppm}$ with the deduction time for 24 hours.

Preliminary test results for heating temperatures at $60^{\circ} \mathrm{C}$ were $5 \%$ of the larvae was dead at a concentration of $1 \mathrm{ppm}$, while $95 \%$ died at a level of $27 \mathrm{ppm}$. As for the heating temperature of $40^{\circ} \mathrm{C}, 5 \%$ of the larvae died at a concentration of $2 \mathrm{ppm}$, while $95 \%$ died at a level of $30 \mathrm{ppm}$.

\section{Final Test of Srikaya Seed Extract Granules}

Based on the results of the preliminary test, the level of concentrations for $60^{\circ} \mathrm{C}$ are 1 ppm, 7 ppm, 14 ppm, 21 ppm, 28 ppm, and 35 $\mathrm{ppm}$. The level of concentrations for $40^{\circ} \mathrm{C}$ are 1 ppm, 6 ppm, 12 ppm, 18 ppm, 24 ppm, and 30 ppm.

The study was conducted by inserting 20 test larvae into a concentration solution, and each concentration was performed four times. Control treatments use aquadest and abate. The observation was then carried out for 24 hours.

\section{Data Analysis}

a. Calculation of the mortality of Aedes aegypti larvae from the administration of srikaya (Annona squamosa L.) seed extract granules follows the formula:

$$
\text { Mortality }=\frac{\text { Number of dead larvae }}{\text { Number of tested larvae }} \times 100 \%
$$

b. Correction of larvae mortality percentage if the control treatment shows $5-20 \%$ of larvae mortality. The Abbot formula corrects the percentage:

$$
\text { Mortality }(\%)=\frac{x-y}{x} \times 100 \%
$$

c. Determination of the LC50 value over 24 hours period of serial concentrations uses the probit analysis.

\section{RESULTS ANN DISCUSSION}

a. Identification of Aedes aegypti L. Eggs

The picture below is the eggs of Aedes aegypti $\mathrm{L}$. The shape and color of eggs that are ready to hatch are oval and black eggs.

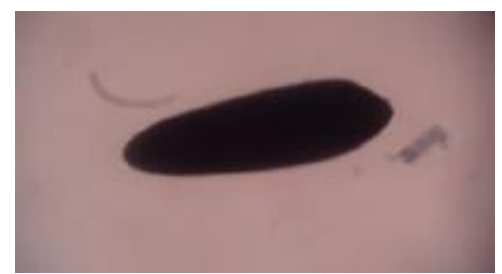

Picture. 1 Aedes aegypti L. Mosquito Egg, with a magnification of $74 \mathrm{x}$ (Personal Documentation).

b. Identification of Aedes aegypti L. Larvae The typical morphology of the mosquito larvae of Aedes aegypti L. is the elongated body shape, blackish-brown body. It has lateral hair on each segment of its body, and has a breathing funnel or siphon with fat and short form. It also has a blunt tip located in the ninth segment. Healthy larvae are moving actively and stay near to the water surface most of the time.

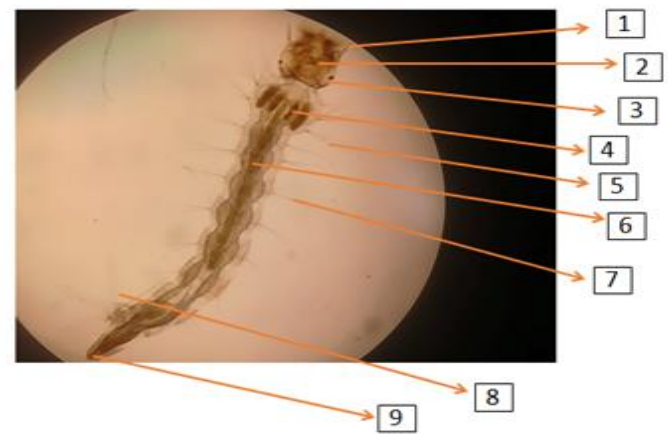

Picture. 2 Microscopic identification of Aedes aegypti $\mathrm{L}$. Larvae with a magnification of $10 \mathrm{x}$ with information: (1) Antenna (2) Head (head) (3) Eyes (4) Chest (thorax) (5) Lateral spine (6) Stomach (7)) Lateral hair (8) Gills (9) Respiratory funnel (Image: Personal Documentation).

This study also observed the morphology of the larvae after treatment. In contrast to the 
healthy larvae, post-treatment larvae experienced spinal loss (thorns), and the body became pale, more transparent, and lysis (broken). The body elongated and swelled from the usual size, and became weak in the water.

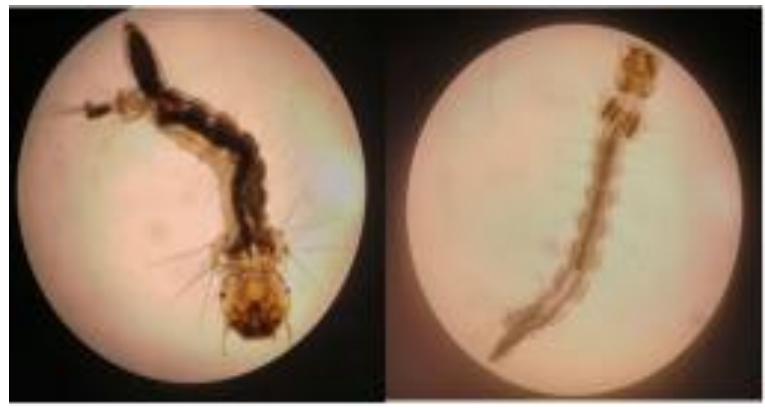

Picture. 3 Differences in Aedes aegypti L. mosquito larvae before being treated with srikaya seed extract (Annona squamosa L.) (A) and after being treated with srikaya seed extract granules (Annona squamosa L.) (B) with a concentration of $30 \mathrm{ppm}$ in 24 hours with a 100x magnification (Image: Personal Documentation).

\section{c. Preliminary Test Results}

Table. 1 The Mortality (\%) of Aedes aegypti L. Larvae in the Preliminary Test with Annona squamosa L. Seed Extract Granules at $60^{\circ} \mathrm{C}$ in 24 hours.

\begin{tabular}{cccc}
\hline $\begin{array}{c}\text { Concentratio } \\
\mathrm{n}(\mathrm{ppm})\end{array}$ & $\begin{array}{c}\text { Total } \\
\text { Test } \\
\text { Larvae }\end{array}$ & $\begin{array}{c}\text { The number } \\
\text { of dead } \\
\text { larvae }\end{array}$ & $\begin{array}{c}\text { Mortality } \\
(\%)\end{array}$ \\
\hline $\mathrm{K}(-)$ & 20 & 0 & $0 \%$ \\
\hline 1 & 20 & 1 & $5 \%$ \\
\hline 2 & 20 & 4 & $20 \%$ \\
\hline 3 & 20 & 3 & $15 \%$ \\
\hline 25 & 20 & 18 & $90 \%$ \\
\hline 27 & 20 & 19 & $95 \%$ \\
\hline 30 & 20 & 20 & $100 \%$ \\
\hline $\mathrm{K}(+)$ & 20 & 20 & $100 \%$ \\
\hline
\end{tabular}

Table. 1 shows the percentage of mortality from the granules treated with a heating temperature of $60^{\circ} \mathrm{C}$. The $5 \%$ mortality shows at $1 \mathrm{ppm}$ concentration, while the $95 \%$ mortality indicates at $27 \mathrm{ppm}$. Negative control treatment (K-) used distilled water shows $0 \%$ mortality, while positive control $(\mathrm{K}+)$ with abate shows $100 \%$ mortality at $1 \mathrm{ppm}$.

The preliminary test results are used as a reference in determining the serial concentration. Six serial concentrations were set, i.e., 1 ppm, 6 ppm, 12 ppm, 18 ppm, 24 ppm, and $30 \mathrm{ppm}$ with a time of 24 hours.

Table. 2 Mortality (\%) of Aedes aegypti L. Larvae in the Preliminary Test with Annona squamosa L. Seed Extract granules at $40^{\circ} \mathrm{C}$ in 24 hours.

\begin{tabular}{cccc}
\hline $\begin{array}{c}\text { Concentratio } \\
\mathrm{n}(\mathrm{ppm})\end{array}$ & $\begin{array}{c}\text { Total } \\
\text { Test } \\
\text { Larvae }\end{array}$ & $\begin{array}{c}\text { The } \\
\text { number of } \\
\text { dead larvae }\end{array}$ & $\begin{array}{c}\text { Mortali } \\
\text { ty } \\
(\%)\end{array}$ \\
\hline $\mathrm{K}(-)$ & 20 & 0 & $0 \%$ \\
\hline 1 & 20 & 0 & $0 \%$ \\
\hline 2 & 20 & 1 & $5 \%$ \\
\hline 3 & 20 & 2 & $10 \%$ \\
\hline 5 & 20 & 20 & $100 \%$ \\
\hline 25 & 20 & 17 & $85 \%$ \\
\hline 30 & 20 & 19 & $95 \%$ \\
\hline 35 & 20 & 20 & $100 \%$ \\
\hline $\mathrm{K}(+)$ & 20 & 20 & $100 \%$ \\
\hline
\end{tabular}

Table 2 shows the percentage of mortality from the granules treated with a heating temperature of $40^{\circ} \mathrm{C}$. The $5 \%$ mortality shows at 2 ppm concentration, while the $95 \%$ mortality indicates at $30 \mathrm{ppm}$. Negative control treatment (K-) with distilled water shows $0 \%$ mortality, while positive control $(\mathrm{K}+)$ with abate shows $100 \%$ mortality at $1 \mathrm{ppm}$.

The preliminary test results are used as a reference in determining the serial concentration. Six serial concentrations were set, i.e., 2 ppm, 7 ppm, 14 ppm, 21 ppm, 28 ppm, and $35 \mathrm{ppm}$ with a deduction time of 24 hours.

\section{d. Final Test Result}

Table 3 presents the observation results of Aedes aegypti L. larvae mortality with a different heating temperature of Annona squamosa L. seed extract granules.

Table. 3 Mortality (\%) of Aedes aegypti L. larvae with Annona squamosa L. Seed Extract granules at $60^{\circ} \mathrm{C}$ within 24 hours. 


\begin{tabular}{llll}
\hline $\begin{array}{l}\text { Lethal } \\
\begin{array}{l}\text { Oncentrat } \\
\text { ion }(\text { LC) }\end{array}\end{array}$ & $\begin{array}{l}\text { The } \\
\text { concentration of } \\
\text { Mixed Extracts } \\
(\mathrm{ppm})\end{array}$ & $\begin{array}{l}\text { Lower } \\
\text { limit }\end{array}$ & $\begin{array}{l}\text { Upper } \\
\text { limit }\end{array}$ \\
\hline LC 50 & 9,85 & 8,50 & 11,07 \\
\hline
\end{tabular}

The results of Table 5 shows that the concentration of granules needed to kill $50 \%$ of the test larvae at 24 hours is $9.85 \mathrm{ppm}$, with a lower limit of $8.50 \mathrm{ppm}$ and an upper limit at $11.07 \mathrm{ppm}$.

Table 6 Probit Analysis Results of $L C_{50}$ at a heating temperature of $40^{\circ} \mathrm{C}$ with 24 Hours Deduction Time.

\begin{tabular}{llll}
\hline $\begin{array}{l}\text { Lethal } \begin{array}{l}\text { Concentrat } \\
\text { ion }(\text { LC) }\end{array} \\
\text { The }\end{array}$ & $\begin{array}{l}\text { Thentration of } \\
\text { Mixed Extracts } \\
(\mathrm{ppm})\end{array}$ & $\begin{array}{l}\text { Lower } \\
\text { limit }\end{array}$ & $\begin{array}{l}\text { Upper } \\
\text { limit }\end{array}$ \\
\hline LC 50 & 15,37 & 13,81 & 16,76 \\
\hline
\end{tabular}

The results of Table 6 shows that the concentration of granules needed to kill $50 \%$ of the test larvae at 24 hours is $15.37 \mathrm{ppm}$, with a lower limit of $13.81 \mathrm{ppm}$ and an upper limit at $16.76 \mathrm{ppm}$. The lower limit is the lowest concentration that can kill the test larvae by $50 \%$ in 24 hours, while the upper limit is the highest concentration that kills the test larvae by $50 \%$ in 24 hours.

The difference in heating temperature of granules to the mortality rate of the larvae was then analyzed using a paired sample t-test, as presented in Table 7.

Table 7. Paired-sample T-test Statistical Test Results

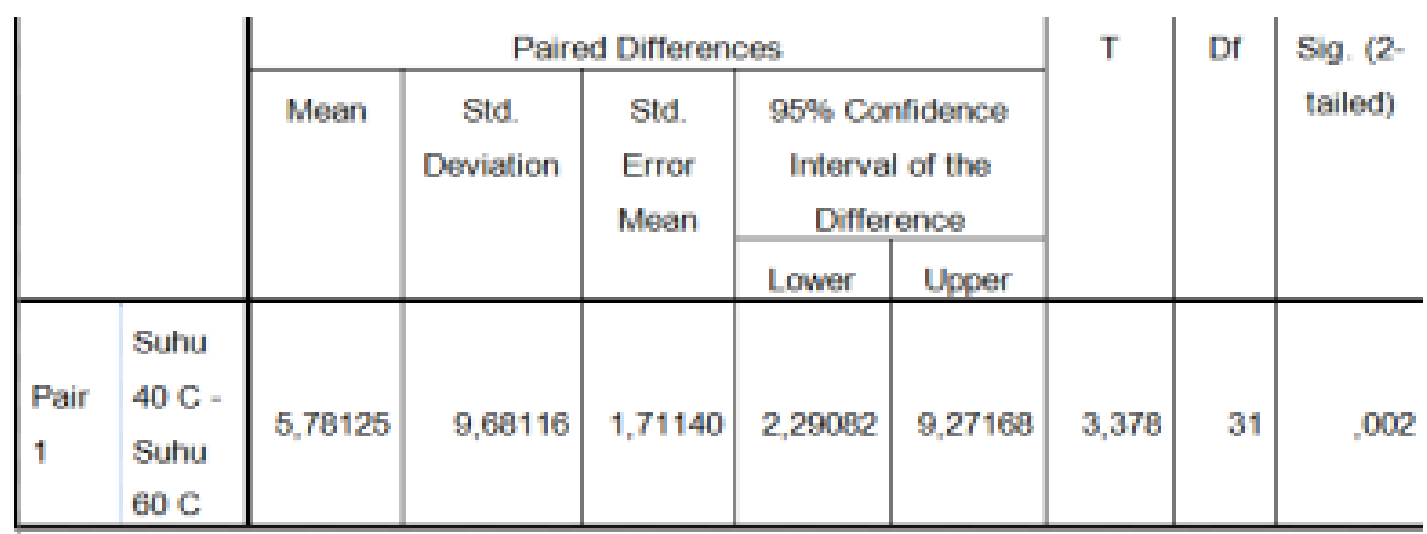

The Table shows there is a significant difference between the mortality rate of Aedes aegypti $\mathrm{L}$. larvae from granules treated with $40^{\circ} \mathrm{C}$ and $60^{\circ} \mathrm{C}$ heating temperature.

\section{e. Discussion}

The results showed that the granules at a concentration of $30 \mathrm{ppm}$ at $40^{\circ} \mathrm{C}$ and $35 \mathrm{ppm}$ at $60^{\circ} \mathrm{C}$ had a strong influence on the death of larvae of Aedes aegypti $\mathrm{L}$. The active compound found in the Annona squamosa seed which served as an insecticide is acetogenin group. Annona seed contains annonain, fat, and resin that functions as contact poisons and stomach poisons in insects. Another active compound are squamosin and asimicin, both are known to inhibit the growth of insects (Kardinan, 2003)
Aedes aegypti L. causes dengue fever. The dengue virus will be active for 8-20 days before it becomes infective. This mosquito actively transmits the virus to humans during the day time (Brown, 1979). If the population of the Aedes aegypti $\mathrm{L}$. Increases, the more the dengue fever occurs and becomes an epidemic.

Chemical insecticides still being used to eradicate Aedes aegypti L. at the larval stage. Not only synthetic insecticides have a side effect of environmental pollution and deadly nontarget animals but also will cause resistance so that the mosquito becomes more robust and immune to pesticides.

The discovery of Annona squamosa L seed extract, which is a new bioinsecticide, is a breakthrough so that it slows the resistance of 
the larvae due to the use of insecticides for a long time.

Annona seed contains annonain, alkaloids, squamosin, and terpenoids. Each compound has a different activity. Annonain and squamosin inhibit the performance of enzyme cholinesterase so that the electron transport process will stop and will cause seizures in the larvae. Alkaloids impede the performance of the hormone edictone, failing the process of metamorphosis in mosquito larvae (Dradjatin, 1988). Other compounds are asymycin, reticulin (bisbinziltetrahydroisokinolin), borneol, camphor, terpene, fatty oil, resin, and toxicant (irritant). Asymycin belongs to the acetogenin group known for its food inhibitor properties (stomach poison) and repellent (contact poison).

A contact poison makes the lipid and wax on the cuticles dissolve so that the active alkaloids compounds will penetrate the thin skins. Once entered the body, it will spread all over, poison the larva, and cause the larva to die. A stomach poison degrades the cell membrane and enters the cell. It disrupts the working system of the insect's nerves by inhibiting the acetylcholinesterase enzyme from sending messages to the midgut in the digestive tract causing it to move uncontrollably.

The post-treatment larvae have darker abdominal color compared to the healthy one. They also undergo body elongation due to interference in the mesenteron (small intestine) areas as a result of stomach poison activity. Annonain and squamosin will also disturb the electron transport process. They block the bond between NADH and Ubiquinone, inhibit the binding of NADH enzyme with cytochrome $\mathrm{c}$ reductase. The ATP formation consequently is inhibited, and the respiration process stops. Annonain and squamosin compounds are more toxic than rotenone type compounds (Wardhana, 2005).

Based on Table 4.7, there is a significant difference in larvae mortality between Annona granules treated in $40^{\circ} \mathrm{C}$ and $60^{\circ} \mathrm{C}$. Pellets with $60^{\circ} \mathrm{C}$ heating treatment have higher toxicity compared to $40^{\circ} \mathrm{C}$.

Temperature is very influential on the levels of phenolic content in srikaya seeds (Annona squamosa L.). Temperatures that increase $10^{\circ} \mathrm{C}$ cause a decrease in phenolic levels. However, this study results otherwise, higher temperature shows higher toxicity.
It may happen because of the differences in larval resistance seen from the granule formulation specifications. The difference in low heating temperature will give a longer granule flow time and vice versa. The granule flow time is related to the moisture content in the granules. Under low-temperature heating, the water content in the pellets evaporates less than at higher temperatures (Elmaghfuroh, 2018). Furthermore, the chemical content at $60^{\circ} \mathrm{C}$ is more preserved so that the granules become more active.

Another factor that influences the toxicity level is a constant volume shown as the tapping index (Elmaghfuroh, 2018). The powder particles are in the most compressible condition when the volume is constant. It also means that there are no more air cavities in the granules. However, the tapping index for good pellets is not more than $20 \%$ (Elmaghfuroh, 2018).

\section{CONCLUSION}

Annona seed extract granules with the heating temperature at $60^{\circ} \mathrm{C}$ have a better toxic effect than ones with the heating temperature at $40^{\circ} \mathrm{C}$ on the death of Aedes aegypti L. larvae within 24 hours.

\section{REFERENCE}

Alfiah, N. 2013. Isolasi Chitosan Kulit Udang dan Pemanfaatannya Pada Buah Strawberry (Fragraria annanasa). Skripsi. Jakarta: Uniiversitas Pendidikan Indonesia.

Brown, H.W. 1979. Dasar Parasitologi Klinis (Edisi ketiga). Terjemahan oleh Rukmono. Jakarta: PT Gramedia.

Dradjatin. 1985. Pengujian Toksisitas 4 Jenis Biji Annona muricata Linn terhadap Lalat Rumah (Musca domestica L). Jakarta: Fakultas Biologi Universitas Nasional [Thesis].

Elmaghfuroh, D.R. 2018. Perbedaan Suhu Pemanasan Terhadap Spesifikasi Formulasi Bioinsektisida Granula Ekstrak Daun Sirih (Piper betle) dengan Ekstrak Biji Srikaya. Skripsi. Jember: Repository Unej. 
Hariana, A. 2013. 262 Tumbuhan Obat dan Khasiatnya (Edisi Revisi). Jakarta: Penebar Swadaya.

Hermianto,T., Wiharsi, K., dan T. Sumarsono. 2004. Potensi Ekstrak Biji Srikaya (Annona squamosa) Untuk Mengedalikan Ulat Krop Kubis Crocidolomia pavonama. Agrosains. 6(1): 31-35

Kardinan, A. 2003. Pestisida Nabati, Ramuan dan Aplikasi. Jakarta: PT. Penebar Swadaya.

Kowsalya, K., dan A.H. Wardhana. 2005. Efektifitas Ekstrak Biji Srikaya (Annona squamosa L.) dengan Pelarut Air, Metanol dan Heksan trhadap Mortalitas Larva Caplak Boophilus microplus secara In Vitro: Bogor. JITV 10(2): 134-142.

Kumar, R., 2009. Practical Botany II. Meerut: Rastogi Publication.

Martini, H., J. Guido., dan W. Gino. 2014. Pengaruh Granul Ekstrak Daun Sirih (Piper betle linn) Terhadap Mortalitas Larva Aedes aegypti. https://www .scribd. com/ doc/ 25023 4949/martini-01-2116443 [Diakses pada 10 November 2018].

Sembel, D.T. 2009. Entomologi Kedokteran. Yogyakarta: Kanisius.

Taslimah. 2014. Uji Elifikasi Ekstrak Biji Srikaya (Annona squamosa L.) Sebagai Bioinsektisida dalam Upaya Integrated Vector Management Terhadap Aedes aegypti. Skripsi. Jakarta: Fakultas
Kedokteran dan Ilmu Kesehatan UIN Syarif Hidayatulloh.

Wardhana, A. H. 2005. Efektifitas Ekstrak Biji Srikaya (Annona squamosa L). dengan Pelarut Air, Metanol dan Heksan terhadap Mortalitas Larva Caplak Boophilus microplus secara In Vitro: Bogor. JITV 10(2): 134-142. 